\title{
Mycophenolate mofetil as an immunomodulator in refractory noninfectious uveitis
}

\author{
Micofenolato mofetila como agente imunomodulador no tratamento das uveítes \\ não infecciosas refratárias
}

Ever Ernesto Caso Rodriguez ${ }^{1}$, Viviane Mayumi Sakata ${ }^{1}$, Daniel Cesar Torres Melo Cavalcanti ${ }^{1}$, Juliana Marques Zaghetto $^{1}$, Edilberto Olivalves ${ }^{1}$, Carlos Eduardo Hirata ${ }^{1}$, Joyce Hisae Yamamoto ${ }^{1}$

\begin{abstract}
Purpose: To evaluate the efficacy and tolerance of mycophenolate mofetil (MMF) for the treatment of noninfectious uveitis using the methods advocated by the Standardization of Uveitis Nomenclature (SUN) Working Group and to compare this with other studies of immunosuppression in ocular inflammation.

Methods: Retrospective case series. Patients with noninfectious uveitis, followed at a tertiary Uveitis Service in São Paulo, Brazil, from 2007 to 2014 and receiving oral MMF for a minimum of 6 months, were retrospectively reviewed. After reaching an optimal dose of MMF, patients were evaluated after 6 (T6), 12 (T12), and 24 months (T24). The optimal dose varied for each patient (medium $2.2 \mathrm{~g} /$ day, range 1.0-3.0 g/day). The main outcome measures were: 1 ) success on achieving complete control of inflammation in both eyes and/or oral prednisone dosage reduction to $\leq 10 \mathrm{mg}$ per day, and 2) the length of time required to reduce oral prednisone to $\leq 10 \mathrm{mg} /$ day, partial control of ocular inflammation, and side effects.

Results: In a cohort of 16 patients with refractory noninfectious uveitis, $67 \%$ reached the ideal prednisone dose after 1 year of MMF treatment and 83\% after 2 years of MMF treatment. Complete or partial inflammation control was achieved in $43.7 \%$ at T12. Two patients (14\%) had disease remission after 4.7 years of MMF treatment. Adverse effects were gastrointestinal disturbances, infection, insomnia, and liver function abnormalities at a rate of 0.03 patient-year each.

Conclusions: This small retrospective case series is consistent with the literature concerning the high efficacy and moderate tolerability of MMF in noninfectious uveitis. Observation of patients should be continued for at least 1 year to clearly determine MMF efficacy.
\end{abstract}

Keywords: Uveitis, chronic; Immunosuppressive agents; Mycophenolate mofetil

\section{RESUMO}

Objetivo: Avaliar a eficácia e tolerância do micofenolato de mofetila (MMF) para o tratamento das uveítes não infecciosas refratárias, utilizando os métodos de análises definidos pelo "Standardization of Uveitis Nomenclature Working Group."

Método: Estudo retrospectivo de série de casos. Foram incluídos pacientes com uveíte não infecciosa, em tratamento oral com MMF por um período mínimo de seis meses, acompanhados no Serviço de Uveítes, Hospital das Clínicas, Faculdade de Medicina da Universidade de São Paulo, São Paulo, Brasil, no período de 2007 a 2014. Todos os pacientes faziam uso de pelo menos um imunossupressor e apresentavam doença ocular ativa. Os pacientes foram avaliados aos seis meses (T6), 12 meses (T12) e 24 meses (T24) após atingir a dose ótima do MMF. A média da dose ótima foi 2,2g/dia (intervalo 1,0-3,0g/dia). Os principais desfechos analisados foram: 1) Sucesso no controle total da inflamação em ambos os olhos el ou redução da dose de prednisona oral para $\leq 10 \mathrm{mg} /$ dia; 2) Intervalo até a redução da prednisona oral para $\leq 10 \mathrm{mg} /$ dia, controle parcial de inflamação ocular e efeitos adversos.

Resultados: Na presente coorte com 16 pacientes com uveíte não infecciosa refratária, observou-se 67\% e 83\% de probabilidade de alcançar a dose ideal de prednisona em T12 e T24, respectivamente. Controle total ou parcial da inflamação foi observado em 43,7\% dos pacientes em T12. Dois pacientes (14\%) tiveram remissão da doença após 4,7 anos do início de MMF. Os efeitos adversos foram distúrbios gastrintestinais, infecção, insônia e anormalidade da função hepática com 0,03 eventos paciente-ano $(P P Y)$ respectivamente.

Conclusões: Esta pequena série retrospectiva de casos ratifica os achados na literatura sobre a alta eficácia e tolerância moderada de MMF em uveítes não infecciosas. Uma importante observação é que, para melhor avaliar a eficácia do MMF, deve se esperar o intervalo mínimo de um ano.

Descritores: Uveíte; Imunossupressores; Micofenolato de mofetila

\section{INTRODUCTION}

Intraocular inflammatory diseases are a significant cause of visual impairment and were responsible for $10 \%$ of new cases of blindness in the United States in 1990 (1). In a large retrospective case series from 1996 of 582 patients with uveitis, 18\% went blind in one eye $\mathrm{e}^{(2)}$. Therefore, adequate treatment of inflammatory eye diseases is important for preserving vision. Uveitis can be classified as infectious or noninfectious. In a survey at Uveitis Service, Hospital das Clinicas, University of São Paulo School of Medicine (HC-FMUSP) in 2004, 37\% of all cases of uveitis were noninfectious ${ }^{(3)}$. The current preferred treatment for noninfectious uveitis is based on systemic corticosteroids with or without immunosuppressants or immunomodulators ${ }^{(4,5)}$. More recently, biological agents have been introduced for the treatment of selected cases of noninfectious uveitis ${ }^{(5,6)}$.

The immunosuppressive activity of mycophenolate mofetil (MMF) is based on inhibition of the de novo pathway of purine synthesis by mycophenolic acid (MPA), preventing the replication of T and $B$ lymphocytes ${ }^{(7-9)}$. MMF is effective in the prevention of allograft rejection ${ }^{(7,8)}$ and the treatment of autoimmune diseases ${ }^{(10-13)}$. It inhibits uveitis in animal models ${ }^{(14)}$. In 1998, Kilmartin et al. first reported successful use of MMF as a rescue therapy in nine patients with refractory uveitis ${ }^{(15)}$. Altogether, three prospective case series studies, including 30 patients, have shown that MMF is an efficient immuno-

Submitted for publication: February 11, 2016

Accepted for publication: July 23, 2016

${ }^{1}$ Clínica Oftalmológica, Hospital das Clínicas, Faculdade de Medicina, Universidade de São Paulo, São Paulo, SP, Brasil.

Funding: No specific financial support was available for this study.

Disclosure of potential conflicts of interest: None of the authors have any potential conflicts of interest to disclose.

Corresponding author: Joyce H. Yamamoto, MD, PhD. Rua Diana, 863/91 J - São Paulo, SP 05019-000 - Brazil - E-mail: joycehy@uol.com.br

Approved by the following research ethics committee: Comissão de Ética para Análise de Projetos de Pesquisa da Diretoria Clínica do Hospital das Clinicas (Cappesq, \# 0621/11). 
suppressant to treat refractory noninfectious ocular inflammation and choroid neovascularization ${ }^{(11,12,16)}$. Serious side effects have been described with doses higher than $3 \mathrm{~g}$ per day, e.g., leucopenia, lymphoma, non-melanotic skin cancer, and infections (cytomegalovirus and herpes simplex). At lower doses, the most common side effects are benign, such as diarrhea (in up to $31 \%$ of patients) ${ }^{(7,8)}$. In uveitis, the dose is usually up to $2 \mathrm{~g}$ per day, and side effects are mild and transient. Plasma concentration monitoring of MPA may optimize the use of MMF and minimize its side effects ${ }^{(17)}$.

The present study aimed to further characterize the efficacy of MMF to control refractory noninfectious uveitis in a tertiary Uveitis Service in São Paulo, Brazil.

\section{METHODS}

Patients with noninfectious uveitis followed at the Uveitis Service, Hospital das Clinicas, Faculdade de Medicina, Universidade de São Paulo (HC-FMUSP) from 2007 to 2014 and treated with oral MMF for a minimum of 6 months were retrospectively studied. All patients were being treated with at least one other immunosuppressant when MMF was begun. After reaching an optimal MMF dose, patients were evaluated after 6 (T6), 12 (T12), and 24 months (T24). The optimal MMF dose was defined as $\leq 3 \mathrm{~g} /$ day and/or when primary outcomes were achieved and sustained for at least 6 months. The optimal dose varied for each patient (average $2.2 \mathrm{~g} /$ day, range 1.0-3.0 g/day). This study was approved by the Ethics Commission for Analysis of Research Projects of HC-FMUSP (CapPesq 0621/11).

\section{Data collection}

Patients on MMF therapy were identified from the Uveitis Service, HC-FMUSP database. The following data were collected: age, gender, uveitis characteristics (anatomical diagnosis, duration, previous systemic therapy), and drug efficacy, and adverse effects. Ocular examination at baseline and at follow-up visits included best-corrected visual acuity measured with a Snellen chart, applanation tonometry, and indirect binocular ophthalmoscopy.

\section{DRUg efFicaCy AND tOleRANCE}

Primary outcomes were defined as achieving complete control of inflammation in both eyes and/or oral prednisone dose reduction to $\leq 10 \mathrm{mg}$ per day on two consecutive visits at least 28 days apart. Secondary outcomes evaluated were the time required to reduce oral prednisone to $\leq 10 \mathrm{mg}$ per day, partial control of ocular inflammation, concomitant use of other immunosuppressants, and side effects or MMF discontinuation. Ocular inflammation (i.e., anterior chamber cells, clinical and angiographic macular edema, and retinal vasculitis) was evaluated according to the Standardization of Uveitis Nomenclature proposed by International Uveitis Society ${ }^{(18)}$.

\section{Statistical analysis}

Clinical and epidemiological data were analyzed based on patient characteristics and tabulated as proportions of the study population. Visual acuity measured with a Snellen chart was converted to logMar ${ }^{(16,17)}$. Events are presented as the incidence rate (person-time rate) during the 24 months of observation. The achievement of the primary outcome of oral prednisone dose reduction to $\leq 10 \mathrm{mg} /$ day occurring at any given time after MMF was started is presented as survival curves, created using the Kaplan-Meier product-limit method. All statistical analyses were calculated using GraphPad Prism (version 6.01 for Windows; GraphPad Software, San Diego, California, USA).

\section{RESULTS}

\section{Characteristics of patients included}

Sixteen patients ( 9 male and 7 female), with a mean age of 41 years (range 14 to 57 years), were included in the study (Table 1). Fifteen patients (94\%) had intermediate or posterior/diffuse uveitis. Vogt-Koyanagi-Harada and Behçet diseases were the most frequent etiologies (9 patients, 56\%). All patients had bilateral uveitis.

\section{Previous immunosuppressive treatment}

The duration of and agents for previous systemic immunosuppressive therapy in each patient is shown in table 2 . Three patients (18.7\%) had previously received one other immunosuppressive drug (cyclosporine A or azathioprine), seven (43\%) had received two (cyclosporine A and azathioprine), and six (37.5\%) had received three or more drugs, amongst which were methotrexate, alkylating agents (chlorambucil, cyclophosphamide), and an anti-tumor necrosis factor a agent (infliximab, adalimumab, or etanercept). Twelve patients were on $>10 \mathrm{mg} /$ day of oral prednisone, with a mean dose at baseline of $25 \mathrm{mg} /$ day (range 15-60 mg/day). Four patients did not receive prednisone.

\section{MMF TREATMENT START AND ITS EFFICACY}

The mean interval from beginning MMF until the optimal dose was achieved was 1.2 years (range $0.5-2.6$ years). At T24, 10 out of 12 patients (83\%) who had required $>10 \mathrm{mg}$ per day of prednisone at T0 were able to reduce the dose to $\leq 10 \mathrm{mg}$ per day (Figure 1). There was an increase in complete and partial inflammation control rates at T12 as compared with T6 (Table 3). Among the 6 patients with a longer follow-up, 2 (33\%) had disease remission after 60 and 40 months of MMF treatment. Functional improvement, measured by an increase in or stabilization of visual acuity, was observed in 12 patients (75\%) after 24 months of MMF (Figure 2).

\section{Side EFFECTS}

Gastrointestinal disturbances were the most frequent complaint requiring MMF dose decrease or discontinuation (in 1 patient) (Table 4). One patient, with a follow-up of 58 months, developed sepsis 51 months after achieving an optimal MMF dose $(3 \mathrm{~g} / \mathrm{d})$. This patient had favorable outcome after appropriate antibiotic therapy.

\begin{tabular}{lcc}
$\begin{array}{l}\text { Table 1. Clinical characteristics of patients with noninfectious uveitis } \\
\text { treated with mycophenolate mofetil }\end{array}$ & \multicolumn{1}{c}{} \\
\hline Number of patients & 16 & $(14-57)$ \\
Median age (years) at the beginning of treatment (range) & & \\
Gender, $n(\%)$ & 9 & $(56)$ \\
Male & 7 & $(44)$ \\
Female & & \\
Uveitis classification, $n$ (\%) & 1 & $(6)$ \\
Anterior & 3 & $(19)$ \\
Intermediate & 3 & $(19)$ \\
Posterior & 9 & $(56)$ \\
Diffuse & & \\
Laterality & 16 & $(100)$ \\
Bilateral & 4.1 & $(1.3-6.5)$ \\
Median disease duration (years) at start of treatment (range) & & \\
Etiology, $n$ (\%) & 5 & $(31 \%)$ \\
Vogt-Koyanagi-Harada disease & 4 & $(25 \%)$ \\
Behçet disease & 3 & $(18 \%)$ \\
Idiopathatic retinal vasculitis & 3 & $(18 \%)$ \\
Intermediate uveitis & 1 & $(6.2 \%)$ \\
Ankylosing spondylitis & & \\
\hline
\end{tabular}


Table 2. Immunosuppressant drugs used prior to mycophenolate mofetil in patients with noninfectious uveitis

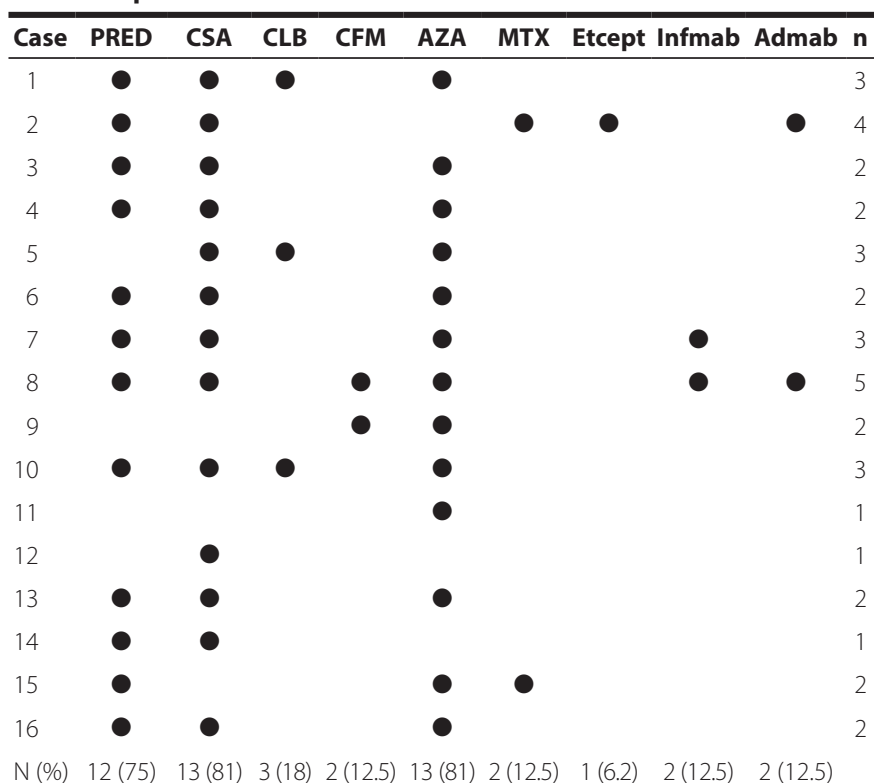

$\mathrm{PRED}=$ prednisone; $\mathrm{CSA}=$ cyclosporine $\mathrm{A} ; \mathrm{CLB}=$ chlorambucil; $\mathrm{CFM}=$ cyclophosphamide; $\mathrm{AZA}=$ azathioprine; $\mathrm{MTX}=$ methotrexate; Etcept= etarnercept; Infmab= infliximab; $\mathrm{Admab}=$ adalimumab.

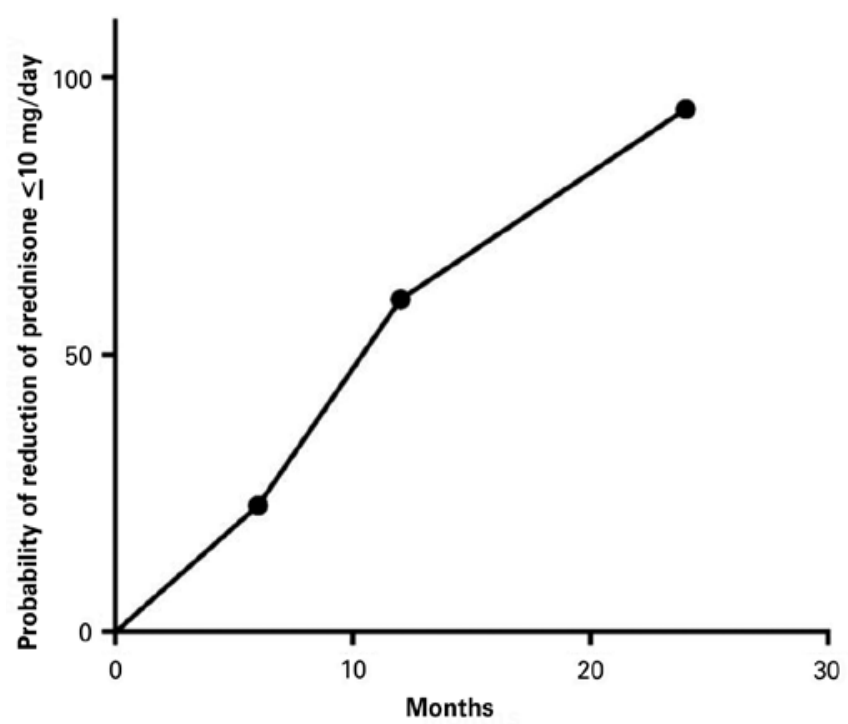

Figure 1. Reduction of prednisone to $\leq 10 \mathrm{mg} /$ day in patients with noninfectious uveitis under mycophenolate mofetil therapy.

\section{DISCUSSION}

In this retrospective case series, MMF was effective in treating refractory noninfectious uveitis.

Most previous studies of MMF in noninfectious uveitis are retrospective. In the five published prospective studies, which included a total of 85 patients, $47 \%$ had better control of inflammation, and $100 \%$ were able to reduce the prednisone dose to $\leq 10 \mathrm{mg}$ per day. Best-corrected visual acuity improved or stabilized in 100\%, achieving $>20 / 40$ in $74 \%$ of patients ${ }^{(11,12,16,19-21)}$. A relevant observation of our present study is that the longer MMF is used, the better the results. Doycheva and Zierhut reported an estimated 94\% to 96\% control of
Table 3. Efficacy of mycophenolate mofetil in patients with noninfectious uveitis after 6 (T6), 12 (T12), and 24 (T24) months of treatment

\begin{tabular}{lccc}
\hline Efficacy & T6, n (\%) & T12, n (\%) & T24, n (\%) \\
\hline Prednisone $\leq 10 \mathrm{mg} /$ day $^{*}$ & $7(58.0)$ & $8(67.0)$ & $10(83.0)$ \\
Inflammation control & & & \\
$\quad$ Complete & $2(12.5)$ & $5(31.2)$ & $5(31.2)$ \\
$\quad$ Partial & $1(6.2)$ & $2(12.5)$ & $2(12.5)$ \\
\hline
\end{tabular}

${ }^{*}=$ data for the 12 patients at T0 who were on prednisone $>10 \mathrm{mg} /$ day.

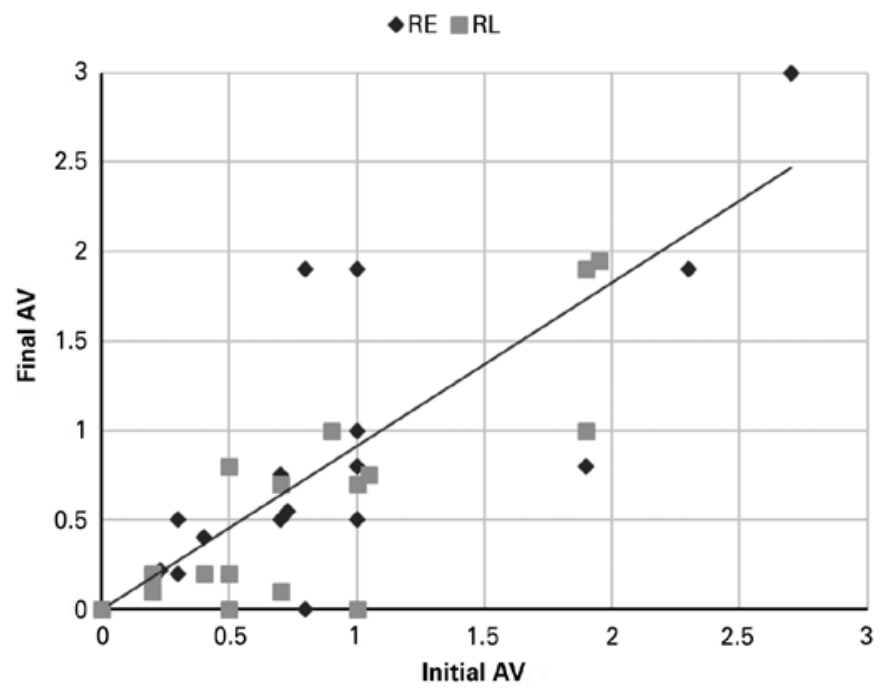

Right eye (RE), dark lozenge; left eye (LE), light square.

Figure 2. Visual acuity at baseline (Initial AV) and at 24 months after beginning mycophenolate mofetil (Final AV) of patients with noninfectious uveitis.

Table 4. Adverse effects of mycophenolate mofetil in patients with noninfectious uveitis

\begin{tabular}{lcc}
\hline Adverse events & n & Rate (events person-year) \\
\hline Gastrointestinal changes & 1 & 0.03 \\
Headache and insomnia & 1 & 0.03 \\
Infection (sepsis) & 1 & 0.03 \\
Liver function abnormalities & 1 & 0.03
\end{tabular}

inflammation with a prednisone dose of $\leq 10 \mathrm{mg}$ per day after 1 or 2 years of MMF treatment ${ }^{(22)}$. Teoh found an $85 \%$ probability of reducing prednisone to $\leq 10 \mathrm{mg}$ per day after one year of treatment ${ }^{(23)}$. In our case series, $67 \%$ of patients reached this ideal prednisone dose after 1 , and $83 \%$ of patients reached it after 2 years of MMF treatment. It is of note that, at the final evaluation, three patients were not taking any other immunosuppressants, and disease remission was observed in two. Addition of another immunosuppressant during therapy with MMF was not needed in any patient.

The average MMF dose in our study was $2.25 \mathrm{~g} /$ day (range $1-3 \mathrm{~g} / \mathrm{d}$ ), similar to other studies $(20,22,24)$. Most of the side effects in our series were observed with a dose of $3 \mathrm{~g}$ per day (three out of four patients). Doses $\geq 3 \mathrm{~g} /$ day may increase the risk of toxicity ${ }^{(4-6)}$. The appropriate dose may lie between 2 and $3 \mathrm{~g} /$ day and may require individualization depending on the clinical course or other factors, e.g., monitoring of MMF plasma concentrations ${ }^{(17)}$.

MMF was moderately well tolerated, with four patients (25\%) experiencing side effects. Among these was one patient with a severe side effect, i.e., sepsis, after 58 months on MMF. Gastrointestinal 
disturbances are indeed the most frequently described side effect in the literature (23\%-35\% versus $21 \%$ in the present study). The formulation of mycophenolate sodium may improve gastrointestinal symptoms ${ }^{(24)}$. The incidence of infection varies more widely in the literature $\left(10 \%\right.$ to $46 \%$ versus $14 \%$ in the present study) ${ }^{(4,20,23)}$. Therefore, as reported in the literature, MMF is a well-tolerated immunosuppressant with a risk of adverse events similar to methotrexate ${ }^{(20)}$. It is important to note that white blood count cells and liver function should be monitored every three months $s^{(4-6)}$.

In conclusion, this small retrospective case series is consistent with what is reported in the literature concerning the efficacy and tolerability of MMF in noninfectious uveitis. It may take treatment for at least one year to determine the efficacy of MMF.

\section{REFERENCES}

1. Nussenblatt RB. The natural history of uveitis. Int Ophthalmol. 1990;14(5-6):303-8.

2. Rothova A, Suttorp-van Schulten MS, Treffers WF, Kijlstra A. Causes and frequency of blindness in patients with intraocular inflammatory disease. Br J Ophthalmol. 1996; 80(4):332-6.

3. Gouveia EB, Yamamoto JH, Abdalla M, Hirata CE, Kubo P, Olivalves E. Causas de uveíte em serviço terciário em São Paulo, Brasil. Arq Bras Oftalmol. 2004;67(1):139-4.

4. Jabs DA, Rosenbaum JT, Foster CS, et al. Guidelines for the use of immunosuppressive drugs in patients with ocular inflammatory disorders: recommendations of an expert panel. Am J Ophthalmol. 2000;130(4):492-513.

5. Airody A, Heath G, Lightman S, Gale R. Non-infectious uveitis: optimizing the therapeutic response. Drugs 2016; doi 10.1007/s40265-015-0502-y

6. Levy-Clarke G, Jabs DA, Read RW, Rosenbaum JT, Vitale A, Van Gelder RN. Expert panel recommendations for the use of anti-tumour necrosis factor biologic agents in patients with ocular inflammatory disorders. Ophthalmology. 2014;121(3):785-96.

7. Placebo-controlled study of mycophenolate mofetil combined with cyclosporin and corticosteroids for prevention of acute rejection. European Mycophenolate Mofetil Cooperative Study Group. Lancet. 1995;345(8961):1321-5.

8. The Tricontinental Mycophenolate Mofetil Renal Transplantation Group. A blinded, randomized clinical trial of mycophenolate mofetil for the prevention of acute rejection in cadaveric renal transplantation. Transplantation. 1996;61(7):1029-37.

9. Allison AC. Mechanisms of action of mycophenolate mofetil. Lupus. 2005;14:S2-S8.

10. Kim EC, Foster CS. Immunomodulatory therapy for the treatment of ocular inflammatory disease: evidence-based medicine recommendations for use. Int Ophthalmol. 2006; 46(2):141-64.
11. Larkin G, Lightman S. Mycophenolate mofetil. A useful immunosuppressive in inflammatory eye disease. Ophthalmology. 1999;106(2):370-4.

12. Zierhut M1, Stübiger N, Aboalchamat W, Landenberger H, et al. Immunosuppressive therapy with mycophenolate mofetil (CellCept) in treatment of uveitis. Ophthalmologe. 2001;98(7):64751

13. Thorne JE, Jabs DA, Qazi FA, Nguyen QD, Kempen JH, Dunn JP. Mycophenolate mofetil therapy for inflammatory eye disease. Ophthalmology. 2005;112(8): 1472-7.

14. Chanaud NP $3^{\text {rd }}$, Vistica BP, Eugui E, Nussenblatt RB, Allison AC, Gery I. Inhibition of experimental autoimmune uveoretinitis by mycophenolate mofetil, an inhibitor of purine metabolism. Exp Eye Res. 1995;61(4):429-34.

15. Kilmartin DJ, Forrester JV, Dick AD. Rescue therapy with mycophenolate mofetil in refractory uveitis. Lancet. 1998;352(9121):356.

16. Neri P, Manoni M, Fortuna C, Lettieri M, Mariotti C, Giovannini A. Association of systemic steroids and mycophenolate mofetil as rescue therapy for uveitic choroidal neovascularization unresponsive to the traditional immunosuppressants: interventional case series. Int Ophthalmol. 2010;30(5):58390.

17. Llinares-Tello F, Hernández-Prats C, Muñoz-Ruiz C, Selva-Otaolaurruchi J, Ordovás-Baines JP. Monitoring trough plasma concentrations of mycophenolate mofetil in patients with uveitis. J Clin Pharm Ther. 2004;295(1)3-8.

18. Standardization of Uveitis Nomenclature (SUN) Working Group. Standardization of uveitis nomenclature for reporting clinical data: results of the first international workshop. Am J Ophthalmol. 2005;140(3):509-16.

19. GallegoPinazo R, DolzMarco R, MartínezCastillo S, Arévalo JF, DíazLlopis M. Update on the principles and novel local and systemic therapies for the treatment of noninfectious uveitis. Inflamm Allergy Drug Targets. 2013;12(1):3845.

20. Rathinam SR, Babu M, Thundikandy R, Kanakath A, Nardone N. A randomized clinica trial comparing methotrexate and mycophenolate mofetil for noninfectious uveitis. Ophthalmology. 2014;121(10):1863-70.

21. ElAsrar AM, Hemachandran S, AlMezaine HS, Kangave D, AlMuammar AM. The outcomes of mycophenolate mofetil therapy combined with systemic corticosteroids in acute uveitis associated with Vogt Koyanagi-Harada disease. Abu. Acta Ophthalmol. 2012;90(8):e603-8

22. Doycheva D, Zierhut M, Blumenstock G. Long-term results of therapy with mycophenolate mofetil in chronic non - infectious uveitis Graefes Arch Clin Exp Ophthalmol. 2011; 249(8):1235-43

23. Teoh SC, Hogan AC, Dick AD, Lee RW. Mycophenolate Mofetil for the Treatment of Uveitis. Am J Ophthalmol. 2008;146(5):752-60

24. Doycheva D, Jägle H, Zierhut M, Deuter C, Blumenstock G, Schiefer U, et al. Mycophenolic acid in the treatment of birdshot chorioretinopathy long-term follow up. Br $J$ Ophthalmol. 2015;99(1):87-91. 